University of Nebraska - Lincoln

DigitalCommons@University of Nebraska - Lincoln

\title{
Latitudinal and Longitudinal Adaptation of Switchgrass Populations
}

\author{
Michael D. Casler \\ USDA-ARS, michael.casler@ars.usda.gov \\ Kenneth P. Vogel \\ University of Nebraska-Lincoln, kvogel1@unl.edu \\ C. M. Taliaferro \\ Oklahoma State University
}

N. J. Ehlke

J. D. Berdahl

USDA-ARS

See next page for additional authors

Follow this and additional works at: https://digitalcommons.unl.edu/usdaarsfacpub

Casler, Michael D.; Vogel, Kenneth P.; Taliaferro, C. M.; Ehlke, N. J.; Berdahl, J. D.; Brummer, E. C.;

Kallenbach, R. L.; West, C. P.; and Mitchell, R. B., "Latitudinal and Longitudinal Adaptation of Switchgrass

Populations" (2007). Publications from USDA-ARS / UNL Faculty. 1938.

https://digitalcommons.unl.edu/usdaarsfacpub/1938

This Article is brought to you for free and open access by the U.S. Department of Agriculture: Agricultural Research Service, Lincoln, Nebraska at DigitalCommons@University of Nebraska - Lincoln. It has been accepted for inclusion in Publications from USDA-ARS / UNL Faculty by an authorized administrator of DigitalCommons@University of Nebraska - Lincoln. 
Authors

Michael D. Casler, Kenneth P. Vogel, C. M. Taliaferro, N. J. Ehlke, J. D. Berdahl, E. C. Brummer, R. L. Kallenbach, C. P. West, and R. B. Mitchell 


\title{
Latitudinal and Longitudinal Adaptation of Switchgrass Populations
}

\author{
M. D. Casler,` K. P. Vogel, C. M. Taliaferro, N. J. Ehlke, J. D. Berdahl, \\ E. C. Brummer, R. L. Kallenbach, C. P. West, and R. B. Mitchell
}

\begin{abstract}
Switchgrass (Panicum virgatum L.) is a warmseason native grass, used for livestock feed, bioenergy, soil and wildlife conservation, and prairie restoration in a large portion of the USA. The objective of this research was to quantify the relative importance of latitude and longitude for adaptation and agronomic performance of a diverse group of switchgrass populations. Six populations, chosen to represent remnant prairie populations on two north-south transects, were evaluated for agronomic traits at 12 locations ranging from 36 to $47^{\circ} \mathrm{N}$ latitude and 88 to $101^{\circ} \mathrm{W}$ longitude. Although the population $\times$ location interactions accounted for only 10 to $31 \%$ of the variance among population means, many significant changes in ranking and adaptive responses were observed. Ground cover was greater for northern-origin populations evaluated in hardiness zones 3 and 4 and for southern-origin populations evaluated in hardiness zones 5 and 6 . There were no adaptive responses related to longitude (ecoregion). Switchgrass populations for use in biomass production, conservation, or restoration should not be moved more than one hardiness zone north or south from their origin, but some can be moved east or west of their original ecoregion, if results from field tests support broad longitudinal adaptation.
\end{abstract}

M.D. Casler, USDA-ARS, U.S. Dairy Forage Res. Center, 1925 Linden Dr. West, Madison, WI 53706-1108; K.P. Vogel and R.B. Mitchell, USDA-ARS, Univ. of Nebraska-East Campus, P.O. Box 830937, Lincoln, NE 68583-0937; C.M. Taliaferro, Dep. of Plant \& Soil Sciences, Oklahoma State Univ., Stillwater, OK 74078-6028; N.J. Ehlke, Dep. of Agronomy \& Plant Genetics, 1991 Buford Cir., St. Paul, MN 55108-6026; J.D. Berdahl, USDA-ARS, Northern Great Plains Res. Ctr., P.O. Box 459, Mandan, ND 58544; E.C. Brummer, Crop and Soil Sciences Dep., Univ. of Georgia, 111 Riverbend Dr., Athens, GA 30602; R.L. Kallenbach, Division of Plant Sciences, 108 Waters Hall, Univ. of Missouri, Columbia, MO 65211; C.P. West, Dep. of Crop, Soil \& Environmental Sciences, Univ. of Arkansas, 1366 W. Altheimer Dr., Fayetteville, AR 72704-6898. Received 12 Dec. 2006. *Corresponding author (mdcasler@wisc.edu).

Cwitchgrass (Panicum virgatum L.) is a warm-season native grass, Uused for livestock feed and biofeedstock production, soil and wildlife conservation, and prairie restoration in a large portion of the USA. Switchgrass produces a high yield of biomass across a wide geographic range; it is suitable for use on marginal, highly erodable, and droughty soils; it has the potential of sequestering large amounts of atmospheric $\mathrm{C}$ in permanent grasslands; and it provides excellent nesting habitat for migratory birds (Vogel, 2004; Paine et al., 1996; Sanderson et al., 1996). Heat, cold, and drought tolerance within the species has allowed adapted ecotypes to inhabit much of North America, ranging west to the front range of the Rocky Mountains, north to Hudson Bay, and south to the Texas Coastal Plain.

Evolutionary processes including gene migration, random genetic drift, mutation, and natural selection combined with environmental variation due to latitude, altitude, soil type, and precipitation have resulted in significant genetic and phenotypic variation

Published in Crop Sci. 47:2249-2260 (2007).

doi: $10.2135 /$ cropsci2006.12.0780

(C) Crop Science Society of America

677 S. Segoe Rd., Madison, WI 53711 USA

All rights reserved. No part of this periodical may be reproduced or transmitted in any form or by any means, electronic or mechanical, including photocopying, recording, or any information storage and retrieval system, without permission in writing from the publisher. Permission for printing and for reprinting the material contained herein has been obtained by the publisher. 
in switchgrass. Latitude of origin has a significant impact on productivity, survival, and adaptation traits of switchgrass (Sanderson et al., 1999; Casler et al., 2004). Two distinct cytotypes exist in switchgrass, upland and lowland (Hultquist et al., 1996). Upland cytotypes are more adapted to northern latitudes and lowland cytotypes are more adapted to southern latitudes. Furthermore, there is genetic variability for adaptation within each cytotype, both of which have northern and southern types within their geographic range (Casler et al., 2004). Growth rate, photoperiodism, heat tolerance, and cold or freezing tolerance regulate adaptation of switchgrass populations.

Adaptation of switchgrass populations has important implications for both agronomic production and prairie conservation and restoration. Agronomically, it is important to utilize germplasm that has photoperiod traits, morphological plasticity, and stress tolerances that match the environmental characteristics of a particular region (Casler et al., 2004; Boe and Casler, 2005). Photoperiod, morphological, and adaptation traits are all important in prairie restoration and conservation endeavors, to ensure that populations are phenotypically similar and well adapted to local environmental conditions. For this reason, many restoration ecologists recommend that populations be drawn only from collections made locally, although "local" is often difficult to define. USDA hardiness zones, defined in $5.5^{\circ} \mathrm{C}$ increments of mean annual minimum temperature, provide an excellent framework for choosing germplasm for use in agronomic breeding programs and for defining "local" conditions for restoration purposes (Casler et al., 2004). However, little is known about genetic variation that conditions the response of switchgrass populations to longitude and its environmental basis. The objective of this research was to quantify the relative importance of latitude and longitude in regulating the adaptation and agronomic performance of a diverse group of switchgrass populations.

\section{MATERIALS AND METHODS}

Six switchgrass populations were chosen to represent two latitudinal transects based on their site of origin (Table 1; Fig. 1). Each population was derived from one or more remnant prairie populations. Pathfinder and Sunburst have a short selection history for vigor (Boe and Ross, 1998, Newell, 1968b), but are closely representative of their original prairie remnant collections. Seeds from each population were germinated in a greenhouse in January 1999. Seeds of the cultivars Blackwell, Cave-in-Rock, Pathfinder, and Sunburst were obtained from commercial sources. Seeds of WS98-IP and WS98-SB were collected from their respective site of origin in September 1998.

One thousand seedlings of each population were transplanted into isolated crossing blocks at Arlington, WI, in May 1999. Plants were spaced $0.9 \mathrm{~m}$ apart in perpendicular directions. Crossing blocks were isolated from other switchgrass by a minimum of $100 \mathrm{~m}$. Weeds were controlled using a combination of tillage, hand weeding, and application of $1.12 \mathrm{~kg} \mathrm{ha}^{-1}$ alachlor [2-chloro- $N$-(2,6-diethylphenyl)-N-(methoxymethyl) acetamide] with $0.07 \mathrm{~kg} \mathrm{ha}^{-1}$ imazethapyr $\{2-[4,5$-dihydro-4methyl-4-(1-methylethyl)-5-oxo-1H-imidazol-2-yl]-5-ethyl3-pyridinecarboxylic acid\}. Each crossing block was fertilized with $112 \mathrm{~kg} \mathrm{~N} \mathrm{ha}{ }^{-1}$ in May 2000. Bulk seed was harvested from each crossing block with a combine in September 2000. Seed was cleaned and stored at $21^{\circ} \mathrm{C}$ for $5 \mathrm{mo}$, then $3^{\circ} \mathrm{C}$ for 2 wk. Two 0.5-g seed samples of each population were tested for germination using a standard protocol (AOSA, 1998) and used to determine mean seed mass.

Populations were planted at 12 locations representing four of the USDA hardiness zones (Table 2; Fig. 1). A Latin square design was used at all locations. Eleven locations were planted in spring 2001 and Mandan was planted in spring 2002. Plot size and soil type for each location are listed in Table 2. Plots were seeded with a drill, rows were spaced 15 to $20 \mathrm{~cm}$ apart, and the seeding rate was 930 PLS $\mathrm{m}^{-2}$. Weeds were controlled by use of pre- and postemergence herbicides, which varied among locations due to local conditions, needs, and restrictions. Forage growth was harvested, but no data were collected at the end of the first growing season.

Plots were fertilized with $112 \mathrm{~kg} \mathrm{~N} \mathrm{ha}^{-1}$ in spring of $2002-$ 2004 (2003-2005 for Mandan). Heading date was scored for each plot when approximately 10 panicles were fully emerged. When most plots had reached anthesis, each plot was scored for maturity using the numerical version of the Nebraska maturity rating scale (Moore et al., 1991). A random sample of tillers was hand-clipped from each plot at a 9-cm cutting height. Samples were weighed, dried at approximately $60^{\circ} \mathrm{C}$ for 5 to $6 \mathrm{~d}$, and weighed again for dry matter determination. To determine biomass yield, plots were harvested once per year with a flail harvester (0.9-m width) or a sickle-bar mower (1.2-m width), depending on location. Harvest dates ranged from late July at

Table 1. Passport information for six switchgrass populations derived from remnant tallgrass prairies.

\begin{tabular}{|c|c|c|c|c|c|}
\hline Population & Site of origin & Latitude $^{\dagger}$ & Longitude $^{\dagger}$ & Ecoregion $^{\ddagger}$ & Hardiness zone $\S$ \\
\hline Sunburst (S) & Union County, SD & $42^{\circ} 30^{\prime} \mathrm{N}$ & $95^{\circ} 30^{\prime} \mathrm{W}$ & 251 (PPT) & $4 b$ \\
\hline Pathfinder $(P)$ & Southeastern Nebraska & $41^{\circ} 00^{\prime} \mathrm{N}$ & $96^{\circ} 00^{\prime} \mathrm{W}$ & 251 (PPT) & $5 b$ \\
\hline Blackwell (B) & Blackwell, OK & $36^{\circ} 49^{\prime} \mathrm{N}$ & $97^{\circ} 17^{\prime} \mathrm{W}$ & 332 (GPS) & $6 b$ \\
\hline WS98-SB (W) & Sterling Barrens State Natural Area, WI & $45^{\circ} 05^{\prime} \mathrm{N}$ & $92^{\circ} 50^{\prime} \mathrm{W}$ & 212 (LMF) & $3 b$ \\
\hline WS98-IP (I) & Ipswitch Prairie State Natural Area, WI & $42^{\circ} 34^{\prime} \mathrm{N}$ & $90^{\circ} 24^{\prime} \mathrm{W}$ & 222 (EBFC) & $4 b$ \\
\hline Cave-in-Rock (C) & Cave-in-Rock, IL & $37^{\circ} 29^{\prime} \mathrm{N}$ & $88^{\circ} 10^{\prime} \mathrm{W}$ & 222 (EBFC) & $6 b$ \\
\hline
\end{tabular}

†Latitude and longitude are approximate for Pathfinder and Sunburst, both of which were derived from several remnant prairies in the vicinity.

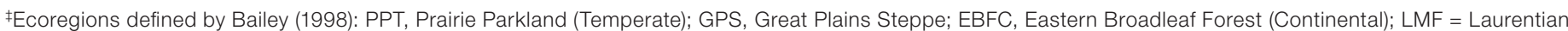
Mixed Forest.

\$Hardiness zones defined by Cathey (1990). 


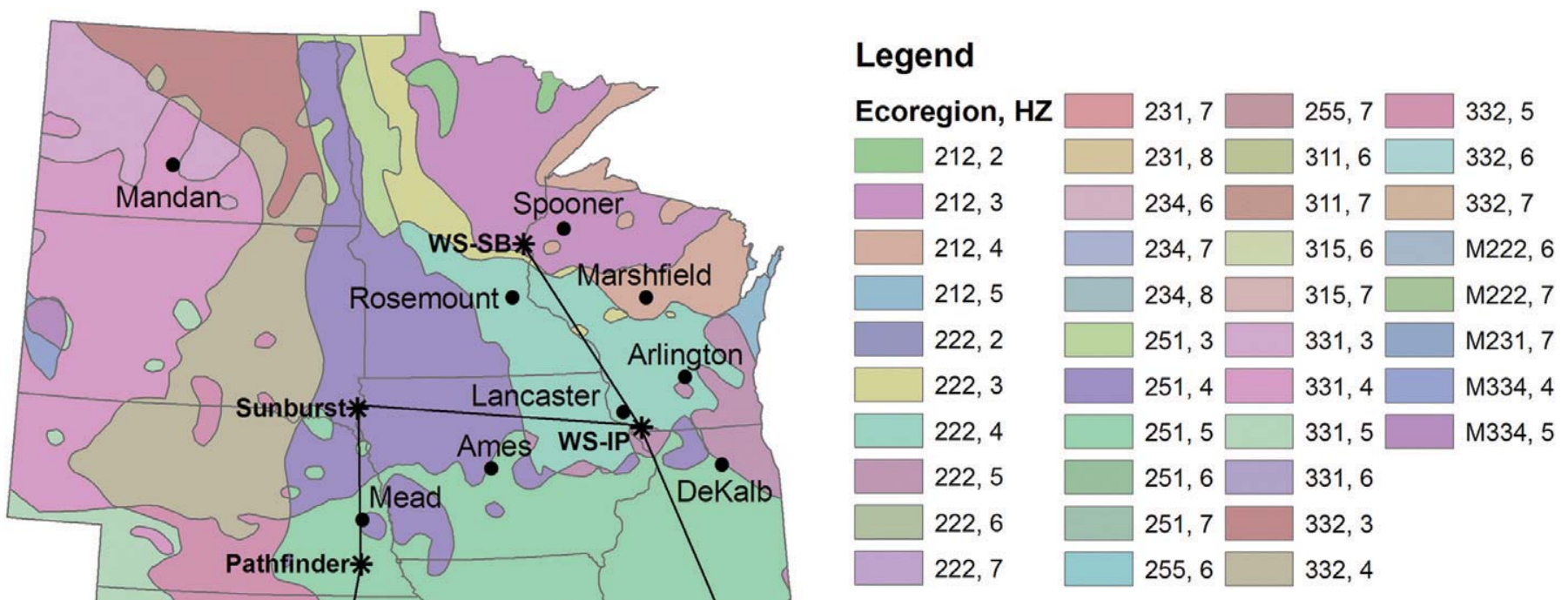

Figure 1. Plant Adaptation Region map for the central USA, showing the location of 12 test sites and the origin of six switchgrass populations. Plant Adaptation Regions (Vogel et al., 2005) are defined by a combination of Ecoregion provinces (Bailey, 1997; 1998) and USDA plant hardiness zones, HZ (Cathey, 1990). Ecoregion province names are as follows: $212=$ Laurentian Mixed Forest; $222=$ Eastern Broadleaf Forest (Continental); 231 = Southern Mixed Forest; 234 = Lower Mississippi Riverine Forest; M222 = Ozark Broadleaf Forest-Meadow; M231 = Ouachita Mixed Forest-Meadow; M234 = Black Hills Coniferous Forest; 251 = Prairie Parkland (Temperate); 255 = Prairie Parkland (Subtropical); 311 = Great Plains Steppe and Shrub; 315 = Southwest Plateau and Plains Dry Steppe and Shrub; 331 = Great Plains and Palouse Dry Steppe; and 332 = Great Plains Steppe. Lines connecting Sunburst, Pathfinder, and Blackwell indicate the north-south transect in the Prairie Parkland ecoregion. Lines connecting WS-SB, WS-IP, and Cave-in-Rock indicate the north-south transect in the Eastern Forest ecoregion. Lines connecting Sunburst with WS-IP and Blackwell with Cave-in-Rock indicate the east-west comparison of Prairie Parkland vs. Eastern Forest ecoregions.

the southernmost locations to mid-September at the northernmost locations and were timed for late anthesis or postanthesis. Plot biomass yields were adjusted to a dry matter basis. Ground cover was determined with two random placements of a 25-cell grid with a cell size of 15 by $15 \mathrm{~cm}$ (Vogel and Masters, 2001), once after initial spring growth and once after harvest in each year. Data were collected for 3 yr at all locations, except Fayetteville (two years only).

Biomass yield data were analyzed by nearest neighbor analysis using separate row and column covariates and ignoring all population and block effects for each location-year combination (Casler, 1999). The residuals, representing all variation due to populations and blocks, were saved for each location-year combination. The appropriate location-year mean was added to each residual to rescale the residuals to represent the raw data adjusted for spatial variation. Adjusted biomass yield values were analyzed by general linear models analysis of variance, subtracting $2 \mathrm{df}$ from error for each location-year combination (Smith and Casler, 2004). All other variables were analyzed by general linear models analysis of variance, treating populations as a fixed effect and all other factors as random effects.

The population $\times$ evaluation-location interaction was partitioned into contrasts to test specific differences among populations using specific combinations of locations. First, the six populations were partitioned into five single degree of freedom contrasts: ecoregion of origin (Prairie Parkland vs. Eastern Forest), Prairie Parkland-transect linear and nonlinear, and Eastern Forest-transect linear and nonlinear. The ecoregion contrast was computed from four of the six populations, eliminating some confounding effects between ecoregion and hardiness zone (Fig. 1), using Sunburst and WS98-IP from hardiness zone 4 and Blackwell and Cave-in-Rock from hardiness zone 6. Each of these five contrasts was computed for six combinations of the evaluation locations (Table 2; Fig. 1): Prairie Parkland locations (Mandan, ND; Ames, IA; DeKalb, IL; Mead, NE; Columbia, MO; Stillwater, OK), Eastern Forest locations (Spooner, WI; Rosemount, MN; Marshfield, WI; Arlington, WI; Lancaster, WI; Fayetteville, AR), and locations within USDA hardiness zones $3,4,5$, and 6 . Second, population means at each location 
Table 2. Soil types, latitude, longitude, Bailey's ecoregion, USDA hardiness zone, and plot sizes for 12 locations used to evaluate six switchgrass populations.

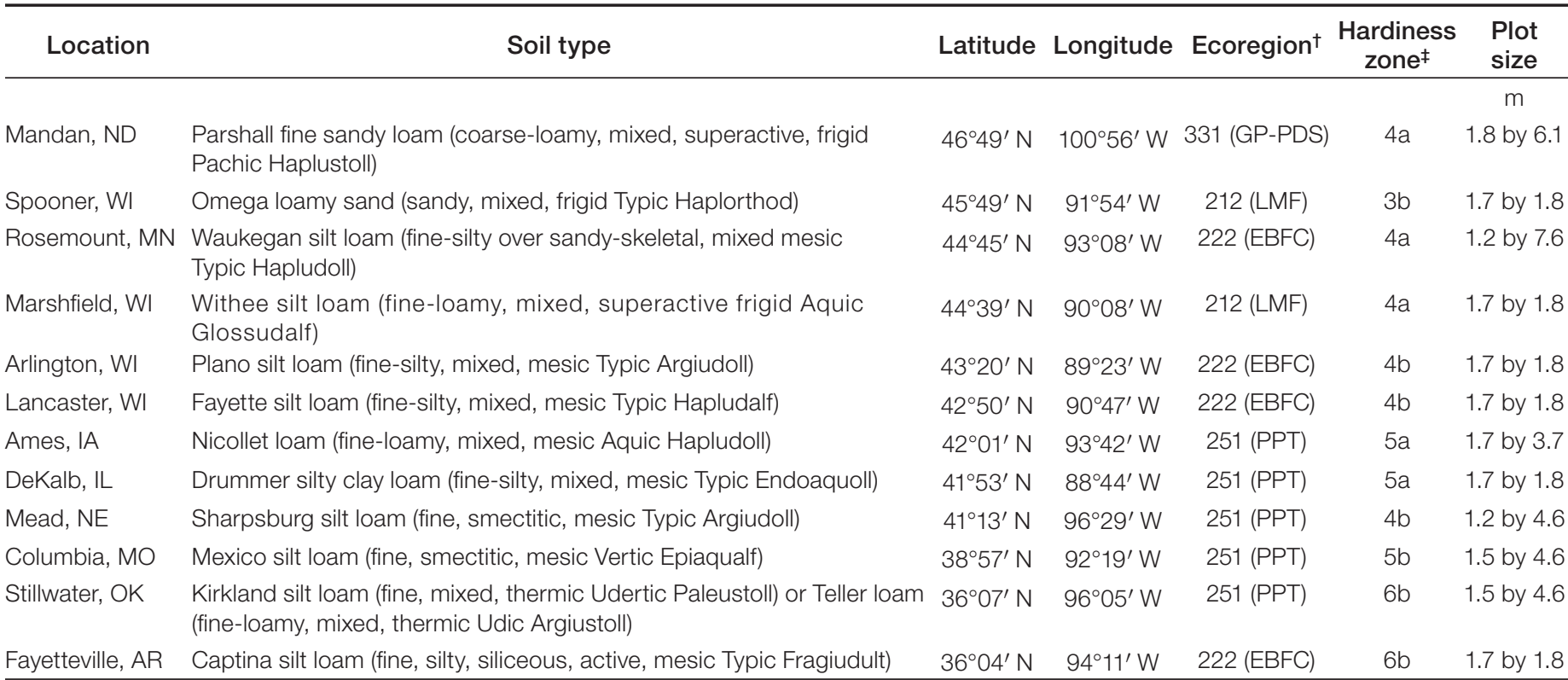

tEcoregions defined by Bailey (1997, 1998): PPT, Prairie Parkland (Temperate); EBFC, Eastern Broadleaf Forest (Continental); GP-PPS, Great Plains-Palouse Dry Steppe; LMF, Laurentian Mixed Forest.

†Hardiness zones defined by Cathey (1990).

were scaled to eliminate the main effect of location by subtracting the location mean from each value (Casler et al., 2004). Scaled means for each population were separately regressed on latitude and longitude of each evaluation location $(n=12)$. All regressions were formulated as linear contrasts using coefficients computed (Carmer and Seif, 1963) and tested in the general linear models ANOVAs (Steel et al., 1996).

\section{RESULTS}

As expected, based on their diverse origins, populations demonstrated significant differences for all variables measured $(\mathrm{P}<$ 0.01). Because all population $\times$ year interactions were nonsignificant, all results were presented as means over years, with the exception of ground cover, which was presented as means approximately $40 \mathrm{mo}$ after planting (late summer of the third harvest year). Conversely, the population $\times$ location interaction was significant $(\mathrm{P}<0.01)$ for all variables, accounting for 10.5 to $13.0 \%$ of the variance of a population mean for heading date, dry matter concentration, and biomass yield, but $31.0 \%$ of the variance of a population mean for ground cover.

The mean growth stage at harvest was mid-anthesis for Blackwell and Pathfinder, late anthesis for Cave-inRock, and postanthesis for the other three populations, corresponding to a range in heading date of $9 \mathrm{~d}$. Maturity at harvest was highly and consistently correlated with heading date at all 12 locations (mean $r=-0.83 \pm 0.06$ ), so the maturity rating was excluded from all further data analyses and presentations.

Ground cover measurements, taken twice per year for 3 yr, had an autoregressive correlation structure in which measurements made following shorter time intervals were more highly correlated than measurements made following longer time intervals. Averaged over locations, the mean phenotypic correlations of ground cover at 40 mo postplanting with the other ground cover measurements were: $r=0.61 \pm 0.11$ for $12 \mathrm{mo}, r=0.72 \pm 0.06$ for $16 \mathrm{mo}, r=0.63 \pm 0.12$ for $24 \mathrm{mo}$, $r=0.81 \pm 0.06$ for $28 \mathrm{mo}$, and $r=0.95 \pm 0.02$ for $36 \mathrm{mo}$. Based on these results and their consistency across locations, ground cover at approximately 40 mo was used in all further analyses and presentations.

The three populations originating in the Prairie Parkland ecoregion were later in heading than the three populations originating in the Eastern Forest ecoregion (Table 3). This difference was similar for trials at Prairie Parkland and Eastern Forest locations, and there were no consistent trends for variation in this effect measured on a north-south transect across hardiness zones 3 to 6 . The ecoregion effect accounted for an average of $24 \%$ of the variation among the six populations.

Populations originating from more southern sites were later in heading, regardless of the evaluation location (Table 3). Regressions of heading date on latitude of origin were negative and significant $(P<0.01)$ for all ecoregions and hardiness zones. On average, populations were $0.8 \mathrm{~d}$ earlier in heading for each degree of latitude change toward the north. This effect was similar in magnitude between Prairie Parkland and Eastern Forest locations and across hardiness zones 3 to 6 . The linear portions of this relationship accounted for an average of $49 \%$ of the variation among the six populations.

The Prairie Parkland populations had greater dry matter concentration than the Eastern Forest populations for all but one of the location groups (Table 4). This effect accounted for an average of $19 \%$ of the variation among 
Table 3. Population $\times$ location analysis for heading date of six switchgrass populations evaluated at 12 locations, grouped by ecoregions and hardiness zones.

\begin{tabular}{|c|c|c|c|c|c|c|c|}
\hline \multirow{2}{*}{$\begin{array}{l}\text { Population, group, and } \\
\text { source of variation }\end{array}$} & \multicolumn{7}{|c|}{ Evaluation location group ${ }^{\dagger}$} \\
\hline & $\begin{array}{c}\text { Prairie } \\
\text { Parkland }\end{array}$ & $\begin{array}{c}\text { Eastern } \\
\text { Forest }\end{array}$ & $\begin{array}{c}\text { Hardiness } \\
\text { zone } 3\end{array}$ & $\begin{array}{c}\text { Hardiness } \\
\text { zone } 4\end{array}$ & $\begin{array}{l}\text { Hardiness } \\
\text { zone } 5\end{array}$ & $\begin{array}{l}\text { Hardiness } \\
\text { zone } 6\end{array}$ & Mean \\
\hline & & & 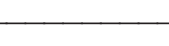 & Day of year (d) & -1 & 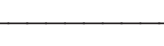 & - \\
\hline Sunburst & 204 & 198 & 202 & 207 & 204 & 178 & 201 \\
\hline Pathfinder & 212 & 203 & 207 & 215 & 206 & 187 & 208 \\
\hline Blackwell & 213 & 203 & 207 & 215 & 206 & 190 & 208 \\
\hline WS-SB & 206 & 197 & 200 & 208 & 205 & 180 & 202 \\
\hline WS-IP & 202 & 197 & 198 & 206 & 205 & 174 & 199 \\
\hline Cave-in-Rock & 209 & 202 & 204 & 212 & 208 & 183 & 206 \\
\hline \multicolumn{8}{|l|}{ Ecoregion means } \\
\hline Prairie Parkland & $208^{* *}$ & $201^{* *}$ & $205^{* *}$ & $211^{* *}$ & 205 & $184^{* *}$ & $204^{* *}$ \\
\hline Eastern Forest & 206 & 199 & 201 & 209 & 206 & 178 & 202 \\
\hline \multicolumn{8}{|l|}{ Hardiness zone transect slopes ${ }^{\ddagger}$} \\
\hline Prairie Parkland & $-1.2^{* *}$ & $-0.8^{* *}$ & $-0.7^{\star *}$ & $-1.1^{* *}$ & $-0.3^{* *}$ & $-1.8^{\star *}$ & $-1.0^{* *}$ \\
\hline Eastern Forest & $-0.5^{* *}$ & $-0.7^{* *}$ & $-0.7^{* *}$ & $-0.7^{* *}$ & $-0.4^{* *}$ & $-0.5^{* *}$ & $-0.6^{* *}$ \\
\hline \multicolumn{8}{|l|}{ Source of variation } \\
\hline Ecoregion & 14 & 6 & 35 & 10 & 18 & 26 & 11 \\
\hline Prairie Parkland transect, linear & 35 & 33 & 16 & 34 & 19 & 38 & 35 \\
\hline Prairie Parkland transect, nonlinear & 22 & 15 & 11 & 23 & 15 & 11 & 19 \\
\hline Eastern Forest transect, linear & 14 & 39 & 25 & 25 & 42 & 7 & 23 \\
\hline Eastern Forest transect, nonlinear & 17 & 6 & 13 & 9 & 5 & 18 & 12 \\
\hline
\end{tabular}

${ }^{* *}$ Ecoregion means significantly different from each other or slope significantly different from zero at $\mathrm{P}<0.01$.

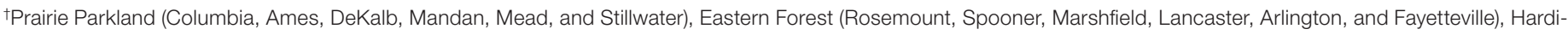

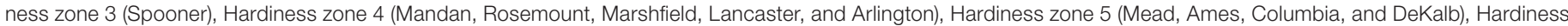
zone 6 (Stillwater and Fayetteville), Mean (all 12 locations).

fLinear regressions of population means on latitude of population origin.

§ach sum of squares has $1 \mathrm{df}$, so comparisons among SS within columns provide a direct measure of the amount of variance explained by each source of variation.

the six populations. There were distinct trends toward a greater effect measured at Prairie Parkland locations and at the more southern locations.

There was a strong positive effect of latitude of origin on dry matter concentration, but only when measured at the Eastern Forest locations and in hardiness zones 3 and 4 (Table 4). Heading date and dry matter concentration were negatively correlated with each other at the six Eastern Forest locations (mean $r=-0.72 \pm 0.14$ ), but this correlation was not significant for the six Prairie Parkland locations (mean $r=-0.42 \pm 0.21$ ). The linear effects of latitude of origin accounted for 62 to $82 \%$ of the variation among the six populations at the most eastern and northern locations.

The Prairie Parkland populations produced 3.4 to $7.2 \%$ greater biomass yield for all six of the evaluation-location groups (Table 5). Each of these differences was significant, except for HZ3 $(P=0.09)$, but this was only due to the low precision associated with one location within this hardiness zone. These effects were highly uniform across the range of location groups and accounted for an average of $13 \%$ of the variation among the six populations.

Although most of the variation among populations in biomass yield could be attributed to hardiness zones or latitude, it was generally nonlinear in nature, indicating the presence of unknown factors that contributed to the variation in biomass yield. Despite this, there were some small linear effects of latitude (Table 5). Biomass yield decreased with increasing latitude of origin for both transects measured at the Prairie Parkland locations and in hardiness zone 5 (i.e., northern populations tended to have lesser biomass yields than southern populations). These linear effects accounted for 25 to $39 \%$ of the variation among populations.

Populations originating in the Prairie Parkland were significantly greater $(P<0.01)$ in ground cover than populations originating in the Eastern Forest for all six location groups (Table 6). This effect accounted for 17 to $56 \%$ of the variation among populations and was generally uniform across location groups.

Ground cover increased significantly $(P<0.01)$ as a function of latitude of origin for both transects measured in hardiness zone 3 and for the Prairie Parkland transect measured in hardiness zone 4 (Fig. 2). Ground cover decreased significantly $(P<0.01)$ as a function of latitude of origin for both transects measured in hardiness zone 5 and for the Eastern Forest transect measured in hardiness zone 6. The linear components of these transects accounted for 11 
Table 4. Population $\times$ location analysis for dry matter concentration of six switchgrass populations evaluated at 12 locations, grouped by ecoregions and hardiness zones.

\begin{tabular}{|c|c|c|c|c|c|c|c|}
\hline \multirow{2}{*}{$\begin{array}{l}\text { Population, group, } \\
\text { and source of variation }\end{array}$} & \multicolumn{7}{|c|}{ Evaluation location group ${ }^{\dagger}$} \\
\hline & $\begin{array}{c}\text { Prairie } \\
\text { Parkland }\end{array}$ & $\begin{array}{c}\text { Eastern } \\
\text { Forest }\end{array}$ & $\begin{array}{c}\text { Hardiness } \\
\text { zone } 3\end{array}$ & $\begin{array}{c}\text { Hardiness } \\
\text { zone } 4\end{array}$ & $\begin{array}{l}\text { Hardiness } \\
\text { zone } 5\end{array}$ & $\begin{array}{c}\text { Hardiness } \\
\text { zone } 6\end{array}$ & Mean \\
\hline & & & 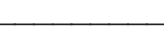 & $-\mathrm{g} \mathrm{kg}^{-1}-$ & - & & - \\
\hline Sunburst & 459 & 447 & 403 & 433 & 435 & 565 & 453 \\
\hline Pathfinder & 432 & 406 & 368 & 394 & 400 & 549 & 419 \\
\hline Blackwell & 445 & 411 & 372 & 395 & 422 & 563 & 428 \\
\hline WS-SB & 446 & 443 & 426 & 418 & 425 & 562 & 444 \\
\hline WS-IP & 435 & 431 & 402 & 421 & 393 & 547 & 433 \\
\hline Cave-in-Rock & 440 & 411 & 367 & 393 & 424 & 554 & 426 \\
\hline \multicolumn{8}{|l|}{ Ecoregion means } \\
\hline Prairie Parkland & $452^{* *}$ & $429^{* *}$ & 388 & $414^{*}$ & $428^{* *}$ & $564^{*}$ & $440^{\star \star}$ \\
\hline Eastern Forest & 438 & 421 & 385 & 407 & 409 & 550 & 429 \\
\hline \multicolumn{8}{|l|}{ Hardiness zone transect slopes ${ }^{\ddagger}$} \\
\hline Prairie Parkland & 1.3 & $4.8^{* *}$ & $4.1^{*}$ & $5.2^{* *}$ & 0.7 & -0.5 & $3.0^{\star *}$ \\
\hline Eastern Forest & 0.5 & $4.2^{* *}$ & $7.6^{* *}$ & $3.5^{* *}$ & -0.9 & 0.7 & $2.3^{\star \star}$ \\
\hline \multicolumn{8}{|l|}{ Source of variation } \\
\hline Ecoregion & 42 & 6 & 0 & 5 & 32 & 51 & 19 \\
\hline Prairie Parkland transect, linear & 6 & 30 & 14 & 36 & 1 & 0 & 21 \\
\hline Prairie Parkland transect, nonlinear & 43 & 32 & 15 & 28 & 32 & 27 & 42 \\
\hline Eastern Forest transect, linear & 1 & 32 & 68 & 27 & 3 & 2 & 16 \\
\hline Eastern Forest transect, nonlinear & 7 & 1 & 2 & 3 & 33 & 20 & 3 \\
\hline
\end{tabular}

"Ecoregion means significantly different from each other or slope significantly different from zero at $\mathrm{P}<0.05$.

"Ecoregion means significantly different from each other or slope significantly different from zero at $\mathrm{P}<0.01$.

'Prairie Parkland (Columbia, Ames, DeKalb, Mandan, Mead, and Stillwater), Eastern Forest (Rosemount, Spooner, Marshfield, Lancaster, Arlington, and Fayetteville), Hardiness zone 3 (Spooner), Hardiness zone 4 (Mandan, Rosemount, Marshfield, Lancaster, and Arlington), Hardiness zone 5 (Mead, Ames, Columbia, and DeKalb), Hardiness zone 6 (Stillwater and Fayetteville), Mean (all 12 locations).

‡Linear regressions of population means on latitude of population origin.

sEach sum of squares has $1 \mathrm{df}$, so comparisons among SS within columns provide a direct measure of the amount of variance explained by each source of variation.

to $31 \%$ of the variation among the six populations (Table 6). Ground cover of both transects was negatively related to latitude of origin at Prairie Parkland locations, but was positively related to latitude of origin at Eastern Forest locations. Ground cover was uniformly correlated with biomass yield across all locations (mean $r=0.72 \pm 0.08$ ).

Six of 24 linear regressions for scaled population means on longitude of evaluation location were significant $(P<0.05$; Fig. 3). Relative to the other populations, Blackwell and Pathfinder headed later at the more western locations, while Pathfinder also had greater dry matter concentration at the more western locations. Blackwell and Pathfinder are both Prairie Parkland populations (Table 1). Conversely, Cave-inRock and WS98-IP were earlier heading at the more western locations, relative to the other populations, while WS98-SB was lower in dry matter concentration at the more western locations. Cave-in-Rock, WS98IP, and WS98-SB are the three Eastern Forest populations (Table 1).

Blackwell, originating from hardiness zone 6 (Fig. 1), decreased in dry matter concentration and ground cover at the more northern locations relative to the other populations (Fig. 4). Cave-in-Rock, also originating from hardiness zone 6 , decreased in ground cover at the more northern locations relative to the other populations. Conversely, WS98-IP, originating from hardiness zone 4 (Fig. 1), increased in ground cover at the more northern locations relative to the other populations.

\section{DISCUSSION}

The lack of importance and statistical significance of population $\times$ year interactions relative to population $\times$ location interactions was consistent with results from previous switchgrass experiments that spanned a wide geographic region (Sanderson and Wolf, 1995; Casler et al., 2004). For smaller geographic regions, population $\times$ year and population $\times$ location interactions tend to be of similar magnitude across a range of traits (Casler and Boe, 2003), particularly when there is considerable variation in weather conditions across years (Hopkins et al., 1995a, 1995b). The importance of population $\times$ location interactions across a wide geographic region implicates a number of environmental variables as fac- 
Table 5. Population $\times$ location analysis for biomass yield of six switchgrass populations evaluated at 12 locations, grouped by ecoregions and hardiness zones.

\begin{tabular}{|c|c|c|c|c|c|c|c|}
\hline \multirow{2}{*}{$\begin{array}{l}\text { Population, group, } \\
\text { andsource of variation }\end{array}$} & \multicolumn{7}{|c|}{ Evaluation location group ${ }^{\dagger}$} \\
\hline & $\begin{array}{l}\text { Prairie } \\
\text { Parkland }\end{array}$ & $\begin{array}{l}\text { Eastern } \\
\text { Forest }\end{array}$ & $\begin{array}{c}\text { Hardiness } \\
\text { zone } 3\end{array}$ & $\begin{array}{l}\text { Hardiness } \\
\text { zone } 4\end{array}$ & $\begin{array}{l}\text { Hardiness } \\
\text { zone } 5\end{array}$ & $\begin{array}{l}\text { Hardiness } \\
\text { zone } 6\end{array}$ & Mean \\
\hline & & & 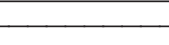 & $-\mathrm{Mg} \mathrm{ha}^{-1}$ & 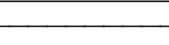 & 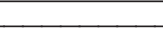 & \\
\hline Sunburst & 7.30 & 10.21 & 10.44 & 8.72 & 6.93 & 10.75 & 8.75 \\
\hline Pathfinder & 7.32 & 9.32 & 9.52 & 8.44 & 7.05 & 9.25 & 8.32 \\
\hline Blackwell & 8.37 & 9.84 & 10.00 & 8.89 & 8.55 & 10.13 & 9.11 \\
\hline WS-SB & 8.20 & 10.50 & 10.82 & 9.17 & 8.26 & 10.78 & 9.35 \\
\hline WS-IP & 6.26 & 9.34 & 9.62 & 7.72 & 5.94 & 9.94 & 7.80 \\
\hline Cave-in-Rock & 8.36 & 10.04 & 9.67 & 8.95 & 8.91 & 10.14 & 9.20 \\
\hline \multicolumn{8}{|l|}{ Ecoregion means } \\
\hline Prairie Parkland & $7.83^{* *}$ & $10.03^{* *}$ & 10.22 & $8.81^{* *}$ & $7.74^{*}$ & $10.44^{*}$ & $8.93^{* *}$ \\
\hline Eastern Forest & 7.31 & 9.69 & 9.64 & 8.33 & 7.42 & 10.04 & 8.50 \\
\hline \multicolumn{8}{|l|}{ Hardiness zone transect slopes ${ }^{\ddagger}$} \\
\hline Prairie Parkland & $-0.20^{\star *}$ & 0.02 & 0.04 & -0.05 & $-0.30^{* *}$ & 0.04 & $-0.09^{* *}$ \\
\hline Eastern Forest & $-0.08^{\star \star}$ & 0.03 & 0.13 & -0.01 & $-0.16^{* *}$ & 0.07 & $-0.02^{*}$ \\
\hline \multicolumn{8}{|l|}{ Source of variation } \\
\hline Ecoregion & 11 & 13 & 27 & 20 & 2 & 14 & 13 \\
\hline Prairie Parkland transect, linear & 17 & 2 & 2 & 2 & 23 & 4 & 6 \\
\hline Prairie Parkland transect, nonlinear & 2 & 30 & 20 & 5 & 2 & 61 & 10 \\
\hline Eastern Forest transect, linear & 8 & 1 & 22 & 1 & 16 & 6 & 3 \\
\hline Eastern Forest transect, nonlinear & 62 & 54 & 28 & 72 & 57 & 16 & 68 \\
\hline
\end{tabular}

${ }^{*}$ Ecoregion means significantly different from each other or slope significantly different from zero at $\mathrm{P}<0.05$.

${ }^{*}$ Ecoregion means significantly different from each other or slope significantly different from zero at $\mathrm{P}<0.01$.

${ }^{\dagger}$ Prairie Parkland (Columbia, Ames, DeKalb, Mandan, Mead, and Stillwater), Eastern Forest (Rosemount, Spooner, Marshfield, Lancaster, Arlington, and Fayetteville), Hardiness zone 3 (Spooner), Hardiness zone 4 (Mandan, Rosemount, Marshfield, Lancaster, and Arlington), Hardiness zone 5 (Mead, Ames, Columbia, and DeKalb), Hardiness zone 6 (Stillwater and Fayetteville), Mean (all 12 locations).

fLinear regressions of population means on latitude of population origin.

§Each sum of squares has $1 \mathrm{df}$, so comparisons among SS within columns provide a direct measure of the amount of variance explained by each source of variation.

tors controlling the relative performance, stability, and plasticity of switchgrass populations.

\section{Latitude and Hardiness Zones}

The populations chosen for this study represented two latitudinal transects, one encompassing hardiness zones 4, 5, and 6 through the Prairie Parkland region (Bailey's ecoregions 332, Great Plains Steppe, and 252, Prairie Parkland), and the other encompassing hardiness zones 3,4 , and 6 through the Eastern Forest region (Bailey's ecoregions 221, Laurentian Mixed Forest, and 222, Eastern Broadleaf Forest Continental; Bailey, 1997, 1998). Both transects were characterized by significant levels of phenotypic variability associated with linear responses to latitude of origin. These responses were simple and generally uniform for heading date, dry matter concentration, and biomass yield, but were complex for ground cover, suggesting differential adaptation of populations.

Populations originating from southern latitudes were later in heading than populations originating from northern latitudes, a result that was consistent with previous studies (McMillan, 1959, 1965; Casler, 2005). Similarly, populations originating from southern latitudes tended to have lower dry matter concentration at harvest than populations originating from northern latitudes, also consistent with previous observations (McMillan, 1965). The relationship between heading date and dry matter concentration was consistent for the Eastern Forest locations, but did not exist for the Prairie Parkland locations. Switchgrass populations from the Prairie Parkland ecoregion are more heterogeneous than other populations (McMillan and Weiler, 1959) and this region appears to be an important center of diversity for this species (McMillan, 1959). Reduced genetic variability or historical genetic bottlenecks (changes in the population due to reduced population size) in Eastern Forest populations may have resulted in a fixed relationship between heading date and dry matter concentration. Larger populations and greater genetic diversity in the Prairie Parkland may support a greater diversity in physiological responses to environmental factors such as photoperiod and temperature, resulting in populations that may be later in heading, but not necessarily lower in dry matter concentration. The overall mean for dry matter concentration was highest at the Prairie Parkland locations and relatively little variation was observed among populations (Table 4). Hot, dry, 
Table 6. Population $\times$ location analysis for ground cover of six switchgrass populations evaluated at 11 locations, grouped by ecoregions and hardiness zones.

\begin{tabular}{|c|c|c|c|c|c|c|c|}
\hline \multirow{2}{*}{$\begin{array}{l}\text { Population, group, } \\
\text { and source of variation }\end{array}$} & \multicolumn{7}{|c|}{ Evaluation location group ${ }^{\dagger}$} \\
\hline & $\begin{array}{c}\text { Prairie } \\
\text { Parkland }\end{array}$ & $\begin{array}{c}\text { Eastern } \\
\text { Forest }\end{array}$ & $\begin{array}{l}\text { Hardiness } \\
\text { zone } 3\end{array}$ & $\begin{array}{l}\text { Hardiness } \\
\text { zone } 4\end{array}$ & $\begin{array}{l}\text { Hardiness } \\
\text { zone } 5\end{array}$ & $\begin{array}{l}\text { Hardiness } \\
\text { zone } 6\end{array}$ & Mean \\
\hline & & & & $\%$ & 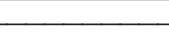 & -2 & - \\
\hline Sunburst & 85 & 91 & 84 & 94 & 74 & 95 & 88 \\
\hline Pathfinder & 84 & 77 & 44 & 89 & 74 & 91 & 81 \\
\hline Blackwell & 93 & 83 & 65 & 91 & 89 & 97 & 88 \\
\hline WS-SB & 85 & 89 & 85 & 91 & 80 & 83 & 87 \\
\hline WS-IP & 73 & 83 & 63 & 88 & 63 & 74 & 77 \\
\hline Cave-in-Rock & 88 & 84 & 61 & 91 & 82 & 92 & 86 \\
\hline \multicolumn{8}{|l|}{ Ecoregion means } \\
\hline Prairie Parkland & $89^{* *}$ & $87^{* *}$ & $74^{* *}$ & $93^{* *}$ & $81^{* *}$ & $96^{* *}$ & $88^{* *}$ \\
\hline Eastern Forest & 80 & 83 & 62 & 89 & 73 & 83 & 82 \\
\hline \multicolumn{8}{|l|}{ Hardiness zone transect slopes ${ }^{\ddagger}$} \\
\hline Prairie Parkland & $-0.3^{* *}$ & $0.8^{* *}$ & $1.5^{* *}$ & $0.4^{* *}$ & $-2.7^{\star *}$ & -0.5 & $-0.4^{*}$ \\
\hline Eastern Forest & $-0.4^{* *}$ & $0.6^{* *}$ & $2.7^{* *}$ & 0.0 & $-0.8^{* *}$ & $-1.6^{* *}$ & $-0.1^{*}$ \\
\hline \multicolumn{8}{|l|}{ Source of variation } \\
\hline Ecoregion & 39 & 16 & 17 & 41 & 24 & 56 & 41 \\
\hline Prairie Parkland transect, linear & 13 & 12 & 5 & 11 & 25 & 1 & 1 \\
\hline Prairie Parkland transect, nonlinear & 3 & 55 & 52 & 27 & 4 & 4 & 22 \\
\hline Eastern Forest transect, linear & 9 & 6 & 14 & 0 & 6 & 21 & 1 \\
\hline Eastern Forest transect, nonlinear & 36 & 10 & 12 & 20 & 40 & 18 & 35 \\
\hline
\end{tabular}

*Ecoregion means significantly different from each other or slope significantly different from zero at $\mathrm{P}<0.05$.

${ }^{*}$ Ecoregion means significantly different from each other or slope significantly different from zero at $\mathrm{P}<0.01$.

†Prairie Parkland (Columbia, Ames, DeKalb, Mandan, Mead, and Stillwater), Eastern Forest (Rosemount, Spooner, Marshfield, Lancaster, Arlington, and Fayetteville), Hardiness zone 3 (Spooner), Hardiness zone 4 (Mandan, Rosemount, Marshfield, Lancaster, and Arlington), Hardiness zone 5 (Mead, Ames, Columbia, and DeKalb), Hardiness zone 6 (Stillwater and Fayetteville), Mean (all 12 locations).

‡Linear regressions of population means on latitude of population origin.

sEach sum of squares has $1 \mathrm{df}$, so comparisons among SS within columns provide a direct measure of the amount of variance explained by each source of variation.

windy weather during late summer or early autumn may have conditioned this response.

Populations originating from southern latitudes tended to have greater biomass yields than populations originating from northern latitudes. Although this effect was not observed uniformly across all evaluation locations, it was observed for both the Eastern Forest and the Prairie Parkland population transects and it is similar to results from two previous studies (Sanderson et al., 1999; Casler et al., 2004). In the Southern Great Plains of the USA, biomass yield is largely a function of plant height (Redfearn et al., 1997; Casler et al., 2004). The longer growing season favors plants with later heading dates and an ability to retain photosynthetically active leaf area longer through the growing season (as indicated by lower dry matter concentration), resulting in more phytomers (more leaves) and taller plants compared to northern genotypes (McMillan, 1964; 1965; Casler et al., 2004; Boe and Casler, 2005). Northern populations grown at southern latitudes tend to flower early and mature more rapidly, reducing their ability to take advantage of the longer growing season. Conversely, southern populations grown at northern latitudes remain vegetative for a lon- ger period of time, flowering later and allowing them to take advantage of longer days and produce higher biomass yields (Newell, 1968a). The linear decline in dry matter concentration of Blackwell (origin in hardiness zone 6) with increasing latitude, relative to the other populations, was consistent with these observations.

McMillan (1959) hypothesized that three gene pools, or primary gene distribution centers, were responsible for repopulation of the tall-grass prairies after the retreat of the Pleiostocene glaciers. A western montane population, originating at southern latitudes, but higher altitudes would have rapidly migrated north, filling the northern ecological zones with early-heading plants capable of sexual reproduction under long-day conditions in a short growing season. A southern population, originating in Texas and Oklahoma, would have possessed considerable genetic variability for photoperiod response, rapidly migrating north throughout the Great Plains and evolving a range of photoperiod and temperature responses as it migrated to higher latitudes and colder climates. A southeastern population would have been responsible for filling ecological niches within the various Eastern Forest ecosystems. Hybridization 
and mixing along contact lines would have occurred frequently and may be partly responsible for much of the genetic variability observed in both chromosome number and morphological traits within many prairieremnant switchgrass populations. McMillan's theory sufficiently explains the existence of latitudinal variability for relatively simple traits such as heading date, dry matter concentration, and biomass yield, that are largely photoperiodic and consistent along latitudinal transects through two distinct ecoregions, the Prairie Parkland and the Eastern Forest.

This was not the case for ground cover. Both latitudinal transects showed distinct adaptive responses for ground cover, suggesting that natural selection is an important factor regulating survival of switchgrass plants and populations. Populations originating from northern latitudes were higher in ground cover, measured in hardiness zones 3 and 4, compared to populations originating from southern latitudes. Similarly, WS98-IP, originating in hardiness zone 4, increased linearly in ground cover relative to the other populations as latitude of evaluation location increased. Blackwell and Cave-in-Rock, originating in hardiness zone 6 , both decreased linearly in ground cover relative to the other populations as latitude of evaluation location increased, consistent with results of Berdahl et al. (2005). Conversely, populations originating from northern latitudes were lower in ground cover, measured in hardiness zones 5 and 6 , compared to populations originating from southern latitudes.

A previous study, based on 5 of the 12 locations utilized in the current study, demonstrated southern adaptation of lowland populations vs. northern adaptation of upland populations, and that northern- and southern-adapted populations can be distinguished within both lowland and upland cytotypes (Casler et al., 2004). The results of this previous study were confirmed by the current study for upland populations of switchgrass, confirming that prairie-remnant populations from hardiness zones 5 and 6 are better adapted to more southern latitudes, while populations from hardiness zones 3 and 4 are better adapted to more northern latitudes, as measured by ground cover 40 mo after planting. Natural selection for survivorship within switchgrass populations is most likely controlled largely by photoperiod and perhaps disease resistance at southern locations, favoring plants that can respond to shorter days with later heading, delayed moisture loss, and an extended photosynthetically active period.
Hardiness Zone $(\mathrm{HZ})$ of Evaluation Locations

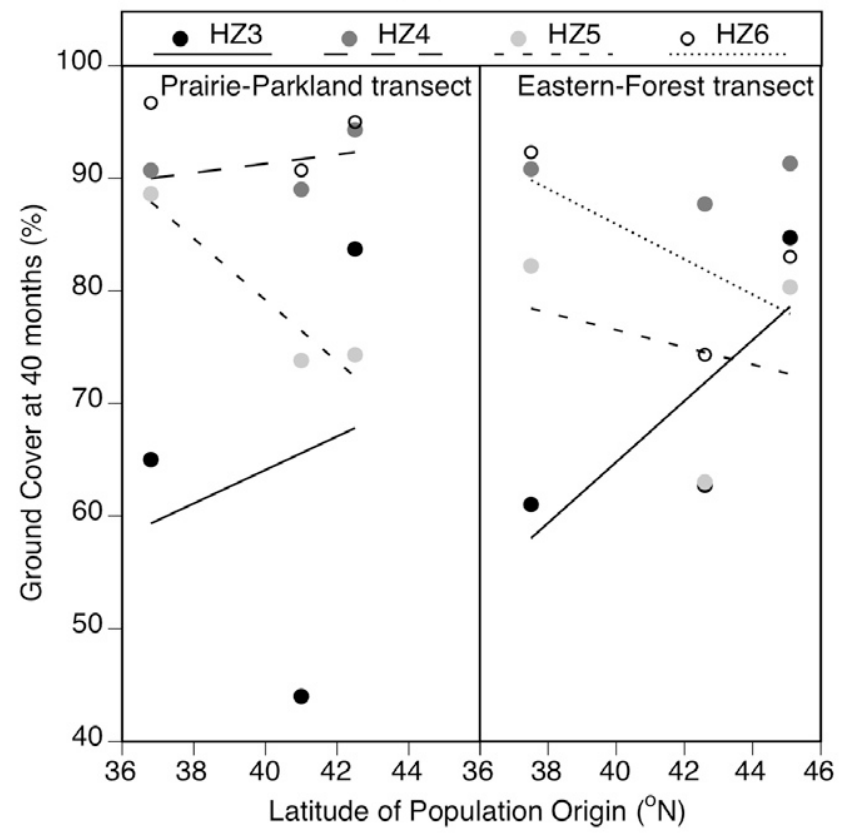

Figure 2. Ground cover, approximately 40 mo after establishment, of six switchgrass populations that form two north-south transects, one through the historical Prairie Parkland ecoregion and one through the historical Eastern Forest ecoregion of the USA. Origins and transects of the six populations are shown in Fig. 1 and Table 1. Linear regression coefficients are shown in Table 6.
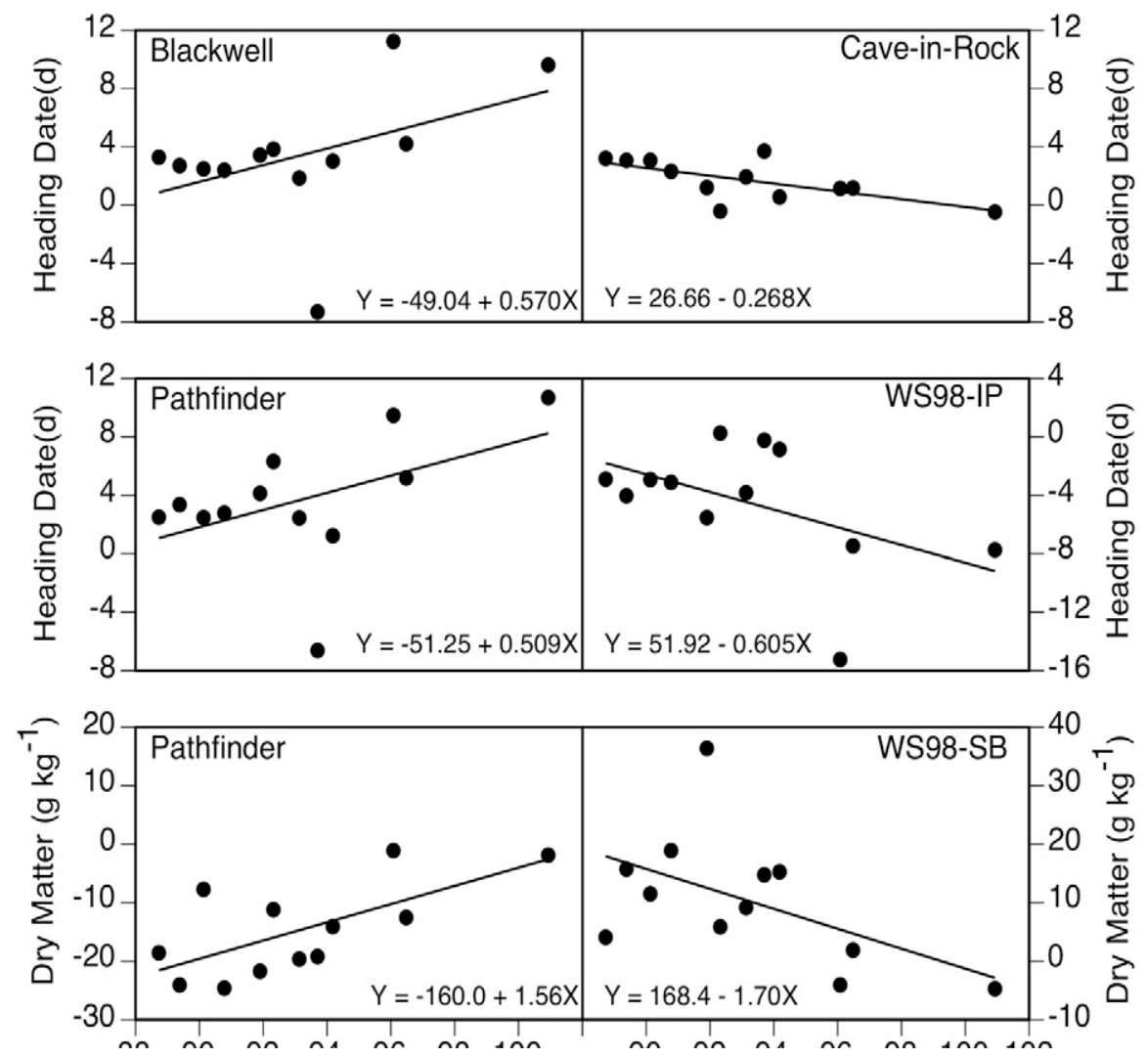

Figure 3. Mean heading date or dry matter concentration of individual populations at 12 evaluation locations, regressed on location longitude. Population means were scaled by subtraction of the location mean to eliminate the main effect of evaluation locations. All displayed regressions were significant at $\mathrm{P}<0.05$; the remaining 18 regressions were not significant (out of 24 total regressions for six populations $\times$ four variables). 

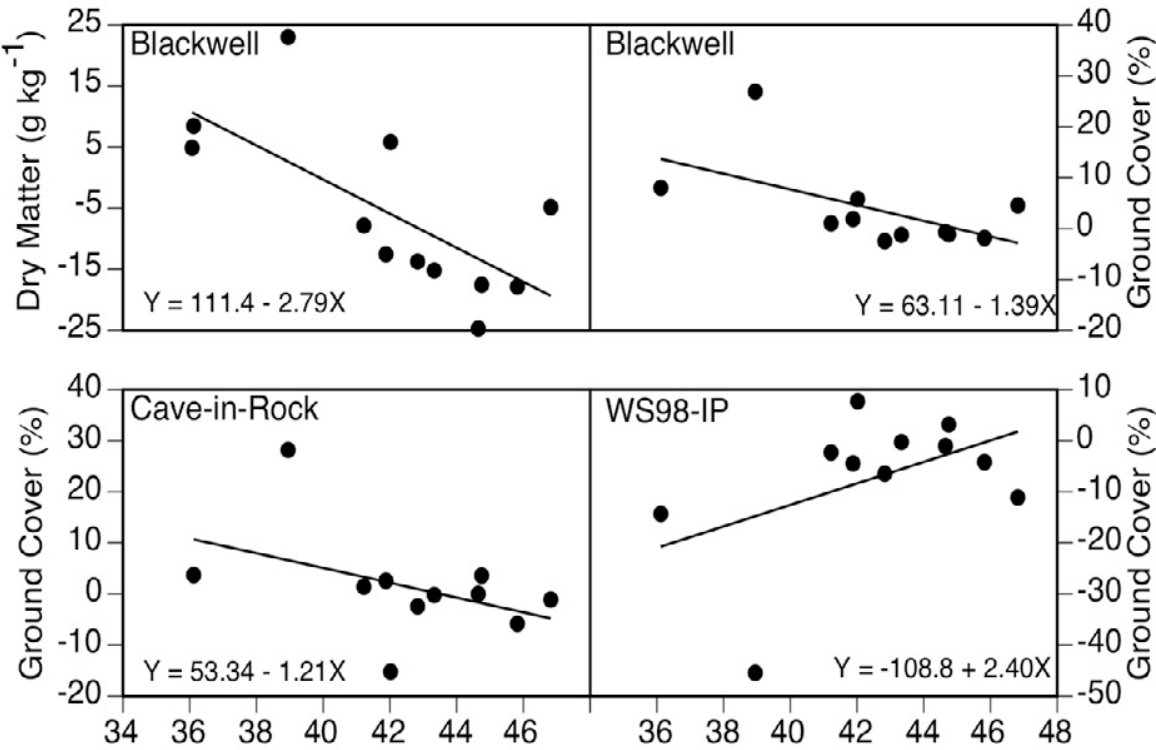

Figure 4. Mean dry matter concentration or ground cover of individual populations at 12 evaluation locations, regressed on location latitude. Population means were scaled by subtraction of the location mean to eliminate the main effect of evaluation locations. All displayed regressions were significant at $\mathrm{P}<0.05$; the remaining 20 regressions were not significant (out of 24 total regressions for six populations $\times$ four variables).

It is likely that southern populations also have greater heat tolerance than northern populations. At northern locations, natural selection for survivorship is likely controlled by cold or freezing tolerance. Most switchgrass mortality occurs during winter months (Casler et al., 2002; unreported data from the current study).

\section{Longitude and Ecoregions}

This is the first study of switchgrass populations specifically designed to test populations for differential adaptation to longitude or ecoregions as defined by Bailey (1998). Other studies have evaluated switchgrass populations across a more limited longitudinal gradient of evaluation locations and found strong (Hopkins et al., 1995a) or weak (Hopkins et al., 1995b) population $\times$ location interactions. In the current study, all four variables were characterized by relatively simple plastic responses, indicating that longitude or ecoregion is not a major factor in regulating adaptive responses of switchgrass.

Prairie Parkland populations were consistently later heading than Eastern Forest populations, a result that is inconsistent with observations made by McMillan (1959), perhaps owing to different germplasm samples. However, four of the six populations had significant linear responses to longitude of the 12 evaluation locations. Two Eastern Forest populations became earlier in heading, relative to the other populations, as they were moved west, while two Prairie Parkland populations became later in heading as they were moved west. These responses resulted in a wide range of heading dates at Prairie Parkland locations, compared to eastern locations. Responses for dry matter concentration were similar in nature to those for heading date, but not as uniform, frequent, or extreme. For both of these traits, it is not possible to differentiate whether these responses resulted from Prairie Parkland populations adapting to the eastern environments, Eastern Forest populations adapting to the western environments, or a combination of the two. Nevertheless, the plasticity of these two traits indicated a clear lack of stability across ecoregions.

Prairie Parkland populations had greater biomass yield and ground cover regardless of the evaluation locations. In contrast, a previous study, which included five Prairie Parkland cultivars and one Eastern Forest cultivar (Cavein-Rock), demonstrated a population $\times$ location interaction that could be considered adaptive in nature (Casler and Boe, 2003). Cave-in-Rock ranked highest in biomass yield and ground cover in southern Wisconsin, but fifth in biomass yield and sixth in ground cover in eastern South Dakota. Furthermore, the correlation between the two locations was $r=0.67$ for biomass yield of all six populations, a value that increased to $r=0.97$ when Cave-in-Rock was removed from the data set. Cave-in-Rock consistently ranks highest in biomass yield relative to cultivars from the Prairie Parkland ecoregion when evaluated in eastern Canada (Madakadze et al., 1998, 1999).

However, the majority of literature supports a lack of adaptive responses associated with longitude or ecoregion. Numerous soil and edaphic factors that differ between the Prairie Parkland and Eastern Forest ecoregions have been investigated as environmental factors that might explain population $\times$ location interactions of switchgrass. Soil texture, soil $\mathrm{pH}$, soil cation exchange capacity, soil $\mathrm{N}$ availability, populations of arbuscular mycorrhizal fungi, and precipitation or moisture availability during the growing season were all important factors discriminating among locations in one or more switchgrass studies (Nixon and McMillan, 1964; Hopkins and Taliaferro, 1997; Brejda et al., 1998; Cassida et al., 2005; Lee and Boe, 2005). In each case there was no evidence for genotype $\times$ environment interaction or interactions could not be described by any of the soil or edaphic factors discriminating the different environmental conditions. Because there is genetic variation for transpiration efficiency in switchgrass (Byrd and May, 2000), there may also be genetic variation for drought tolerance, which would likely have an impact on population $\times$ location interactions of field studies over a larger geographic area, such as westward into the rain shadow of the Rocky Mountains. 
The lack of differential adaptation of eastern- vs. western-origin switchgrass populations suggests that McMillan's theory of three gene pools or centers of deployment following retreat of the Pleistocene glaciers must have been followed by extensive homogenization among the three gene pools (McMillan, 1959, 1964). The principal forces promoting homogenization would be hybridization at population boundaries and gene migration, the latter occurring by wind-borne pollen transport or seed transport by birds, mammals, and humans. The forces promoting homogenization appear to be considerably stronger than any forces promoting adaptive responses to longitude or ecoregions.

\section{Synthesis: Regional Gene Pools}

Switchgrass breeding programs and the seed industry have combined to create a seed marketing and distribution system that encourages and facilitates movement of switchgrass seeds across large regional areas. Due to low profit margins, the seed industry favors high-volume cultivars, which are more likely to result from germplasm that is broadly adapted across multiple ecological zones. Furthermore, there are very few cultivars developed from germplasm that originates east of the Mississippi River, leading to a heavy reliance on a small number of eastern cultivars and a broad distribution of cultivars from the Great Plains (historical Prairie Parkland ecoregion).

Our research has validated the Plant Adaptation Region proposal of Vogel et al. (2005) as fully compatible with empirical agronomic, adaptation, and stability of switchgrass populations. Plant Adaptation Regions, combining hardiness zones (Cathey, 1990) with ecoregions (Bailey, 1997, 1998), are the functional units that define adaptation of switchgrass populations, incorporating photoperiod, average minimum temperature, historic vegetation, and regional soil type into an effective germplasm classification system for both cultivated and natural germplasm.

Some populations are broadly adapted beyond their Plant Adaptation Region of origin, such as Cave-in-Rock, which is adapted to hardiness zones 5,6 , and 7 throughout ecoregion Province 251 and east through most ecoregions to the Atlantic Ocean (Madakadze et al., 1998, 1999; Vogel, 2004). This broad adaptation indicates that cultivars such as Cave-in-Rock have a genetic composition that provides for a robust responsiveness to environmental variables, a valuable characteristic for use in both livestock and feedstock production systems. Germplasm with broad adaptation potential also will be very valuable for long-term conservation plantings if predicted climatic changes occur.

As fossil fuel reserves become more depleted and their effects on Earth's atmosphere become more prominent, the need for renewable and cleaner energy sources increases. Switchgrass will be an essential component of a new paradigm in sustainable energy production systems in
North America. In the USA alone, 16 million ha of productive farmland is set aside every year for conservation purposes (Perlack et al., 2005). This land, combined with many more hectares of marginal cropland, could support bioenergy production from switchgrass, providing many additional socioeconomic benefits derived from permanent grassland (Paine et al., 1996; Vogel, 1996, 2004). Our research indicates that a comprehensive program of developing switchgrass cultivars for use in bioenergy production will require some level of regional breeding in North America (Sanderson et al., 2006). Efforts should continue to focus on large-scale regional testing of new candidate cultivars as the only means of identifying broadly adapted cultivars such as Cave-in-Rock and the limits to their adaptation range. Breeding efforts should continue to focus on regional gene pools, defined by hardiness zones, gathering germplasm from throughout the region, conducting selection in representative environments, and developing large networks of collaborators to support field trials throughout the target hardiness zones.

\section{Acknowledgments}

This research was funded in part by the U.S. Department of Energy Biomass Feedstock Development Program via the Oak Ridge National Lab. Contract No. DE-A105-900R2194. We thank the following individuals for their valuable assistance and support of this research: Lyle Paul, Northern Illinois Agronomy Research Center; Tim Wood, Lancaster Agricultural Research Station; Mike Bertram, Marshfield Agricultural Research Station; Phil Holman, Spooner Agricultural Research Station; Donn Vellekson, Department of Agronomy and Plant Genetics, University of Minnesota; Danny England, Division of Plant Sciences, University of Missouri; Steve Masterson, USDA-ARS, Lincoln, NE; Mike Barker, Department of Agronomy, Iowa State University; Gary Williams, Plant and Soil Sciences Department, Oklahoma State University; and Gordon Jensen, USDA-ARS, Mandan, ND. We thank Marty Schmer, USDA-ARS and University of Nebraska, for valuable assistance in creating Fig. 1.

\section{References}

Association of Official Seed Analysts. 1998. Rules for seed testing. AOSA, Beltsville, MD.

Bailey, R.G. 1997. Ecoregions of North America (rev). Available at http://www.fs.fed.us/colorimagemap/ecoreg1_provinces (verified 18 June 2007). U.S. Forest Service, Washington, DC.

Bailey, R.G. 1998. Ecoregions: The ecosystem geography of the oceans and continents. Springer-Verlag, New York.

Berdahl, J.D., A.B. Frank, J.M. Krupinsky, P.M. Carr, J.D. Hanson, and H.A. Johnson. 2005. Biomass yield, phenology, and survival of diverse switchgrass cultivars and experimental strains in western North Dakota. Agron. J. 97:549-555.

Boe, A., and M.D. Casler. 2005. Hierarchical analysis of switchgrass morphology. Crop Sci. 45:2465-2472.

Boe, A., and J.G. Ross. 1998. Registration of 'Sunburst' switchgrass. Crop Sci. 38:540.

Brejda, J.J., L.E. Moser, and K.P. Vogel. 1998. Evaluation of switchgrass rhizosphere microflora for enhancing seedling yield and nutrient uptake. Agron. J. 90:753-758. 
Byrd, G.T., and P.A. May, II. 2000. Physiological comparisons of switchgrass cultivars differing in transpiration efficiency. Crop Sci. 40:1271-1277.

Carmer, S.G., and R.D. Seif. 1963. Calculation of orthogonal coefficients when treatments are unequally replicated and/or unequally spaced. Agron. J. 55:387-389.

Casler, M.D. 1999. Spatial variation affects precision of perennial cool-season forage grass trials. Agron. J. 91:75-81.

Casler, M.D. 2005. Ecotypic variation among switchgrass populations from the northern USA. Crop Sci. 45:388-398.

Casler, M.D., and A.R. Boe. 2003. Cultivar $\times$ environment interactions in switchgrass. Crop Sci. 43:2226-2233.

Casler, M.D., D.R. Buxton, and K.P. Vogel. 2002. Genetic modification of lignin concentration affects fitness of perennial herbaceous plants. Theor. Appl. Genet. 104:127-131.

Casler, M.D., K.P. Vogel, C.M. Taliferro, and R.L. Wynia. 2004. Latitudinal adaptation of switchgrass populations. Crop Sci. 44:293-303.

Cassida, K.A., J.P. Muir, M.A. Mussey, J.C. Read, B.C. Venuto, and W.A. Ocumpaugh. 2005. Biomass yield and stand characteristics of switchgrass in south central U.S. environments. Crop Sci. 45:673-681.

Cathey, H.M. 1990. USDA plant hardiness zone map. USDA Misc. Publ. No. 1475. Available at http://www.usna.usda. gov/Hardzone/ushzmap.html (verified 18 June 2007). U.S. National Arboretum, USDA-ARS, Washington, DC.

Hopkins, A.A., and C.M. Taliaferro. 1997. Genetic variation within switchgrass populations for acid soil tolerance. Crop Sci. 37:1719-1722.

Hopkins, A.A., K.P. Vogel, K.J. Moore, K.D. Johnson, and I.T. Carlson. 1995a. Genotype effects and genotype by environment interactions for traits of elite switchgrass populations. Crop Sci. 35:125-132.

Hopkins, A.A., K.P. Vogel, K.J. Moore, K.D. Johnson, and I.T. Carlson. 1995b. Genotypic variability and genotype $\times$ environment interactions among switchgrass accessions from the midwestern USA. Crop Sci. 35:565-571.

Hultquist, S.J., K.P. Vogel, D.J. Lee, K. Arumuganathan, and S.M. Kaeppler. 1996. Chloroplast DNA and nuclear DNA content variations among cultivars of switchgrass, Panicum virgatum L. Crop Sci. 36:1049-1052.

Lee, D.K., and A. Boe. 2005. Biomass production of switchgrass in central South Dakota. Crop Sci. 45:2583-2590.

Madakadze, I.C., B.E. Coulman, K.A. Stewart, P.R. Peterson, R. Samson, and D.L. Smith. 1998. Phenology and tiller characteristics of big bluestem and switchgrass cultivars in a short growing season area. Crop Sci. 38:827-834.

Madakadze, I.C., K.A. Stewart, P.R. Peterson, B.E. Coulman, and D.L. Smith. 1999. Switchgrass biomass and chemical composition for biofuel in eastern Canada. Agron. J. 91:696-701.

McMillan, C. 1959. The role of ecotypic variation in the distribution of the central grassland of North America. Ecol. Monogr. 29:285-308.

McMillan, C. 1964. Ecotypic differentiation within four North American prairie grasses. I. Morphological variation within transplanted community fractions. Am. J. Bot. 51:1119-1128.

McMillan, C. 1965. Ecotypic differences with four North American prairie grasses: II. Behavioral variation with transplanted community fractions. Am. J. Bot. 52:55-65.
McMillan, C., and J. Weiler. 1959. Cytogeography of Panicum virgatum in central North America. Am. J. Bot. 46:590-593.

Moore, K.J., L.E. Moser, K.P. Vogel, S.S. Waller, B.E. Johnson, and J.F. Pedersen. 1991. Describing and quantifying growth stages of perennial forage grasses. Agron. J. 83:1073-1077.

Newell, L.C. 1968a. Effects of strain source and management practice on forage yields of two warm-season prairie grasses. Crop Sci. 8:205-210.

Newell, L.C. 1968b. Registration of Pathfinder switchgrass. Crop Sci. 8:516.

Nixon, E.S., and C. McMillan. 1964. The role of soil in the distribution of four grass species in Texas. Am. Midl. Nat. 71:114-140.

Paine, L.K., T.L. Peterson, D.J. Undersander, K.C. Rineer, G.A. Bartelt, S.A. Temple, D.W. Sample, and R.M. Klemme. 1996. Some ecological and socio-economic considerations for biomass energy crop production. Biomass Bioenergy 10:231-242.

Perlack, R.D., L.L. Wright, A.F. Turhollow, R.L. Graham, B.J Stokes, and D.C. Erbach. 2005. Biomass as feedstock for a bioenergy and bioproducts industry: The technical feasibility of a billion-ton annual supply. Available at http://feedstockreview.ornl.gov/pdf/billion_ton_vision.pdf (verified 18 June 2007). USDOE and USDA, Oak Ridge, TN.

Redfearn, D.D., K.J. Moore, K.P. Vogel, S.S. Waller, and R.B. Mitchell. 1997. Canopy architecture and morphology of switchgrass populations differing in forage yield. Agron. J. 89:262-269.

Sanderson, M.A., P.R. Adler, A. Boateng, M.D. Casler, and G. Sarath. 2006. Switchgrass for biomass feedstock in the USA. Can. J. Plant Sci. 86:1315-1325.

Sanderson, M.A., R.L. Reed, S.B. McLaughlin, S.D. Wullschleger, B.V. Conger, D.J. Parrish, D.D. Wolf, C.M. Taliaferro, A.A. Hopkins, W.R. Ocumpaugh, M.A. Hussey, J.C. Read, and C.R. Tischler. 1996. Switchgrass as a sustainable bioenergy crop. Bioresour. Technol. 56:83-93.

Sanderson, M.A., R.L. Reed, W.L. Ocumpaugh, M.A. Hussey, G. Van Esbroeck, J.C. Read, C.R. Tischler, and F.M. Hons. 1999. Switchgrass cultivars and germplasm for biomass feedstock production in Texas. Bioresour. Technol. 67:209-219.

Sanderson, M.A., and D.D. Wolf. 1995. Morphological development of switchgrass in diverse environments. Agron. J. 87:908-915.

Smith, K.F., and M.D. Casler. 2004. The use of spatially adjusted herbage yields during the analysis of perennial forage grass trials across locations. Crop Sci. 44:56-62.

Steel, R.G.D., J.H. Torrie, and D.A. Dickey. 1996. Principles and procedures of statistics: A biometrical approach. 3rd ed. McGraw-Hill, New York.

Vogel, K.P. 1996. Energy production from forages (or American agriculture-Back to the future). J. Soil Water Conserv. 51:137-139.

Vogel, K.P. 2004. Switchgrass. p. 561-588. In L.E. Moser, B.L. Burson, and L.E. Sollenberger (ed.) Warm-season $\left(\mathrm{C}_{4}\right)$ grasses. ASA, CSSA, and SSSA, Madison, WI.

Vogel, K.P., and R.A. Masters. 2001. Frequency grid: A simple tool for measuring grassland establishment. J. Range Manage. 54:653-655.

Vogel, K.P., M.R. Schmer, and R.B. Mitchell. 2005. Plant adaptation regions: Ecological and climatic classification of plant materials. Range Ecol. Manage. 58:315-319. 